\title{
PUTNAM, PRAGMATISM AND THE FATE OF METAPHYSICS
}

\section{DAVID MACARTHUR}

University of Sydney

\begin{abstract}
Putnam has called for a renewal of philosophy by invoking the names of Wittgenstein and Dewey, both strong critics of traditional metaphysics. In the light of his own attacks on various forms of metaphysics (e.g. metaphysical realism, the fact/ value distinction), one question that arises is this: what is the fate of metaphysics in Putnam's vision of philosophy? The present paper explores this question by reading Putnam as committed to a broadly pragmatist approach to metaphysics exemplified in different ways by James and Dewey. I end by providing several different ways of understanding Putnam's claim that "there is a sense in which it is the task of philosophy to overcome metaphysics and a sense in which its task is to continue metaphysical discussion".
\end{abstract}

Keywords: Putnam, metaphysics, pragmatism, James, Dewey
Tn Renewing Philosophy (1992), having surveyed a number of metaphysical programs in contemporary analytic philosophy, including Bernard Williams' appeal to an absolute conception of the world, Ruth Millikan's attempt to reduce intentionality to biological function, and Nelson Goodman's irrealism, Putnam concludes as follows:

I have argued that the decision of a large part of contemporary analytic philosophy to become a form of metaphysics is a mistake. Indeed, contemporary analytic metaphysics is in many ways a parody of the great metaphysics of the past. As Dewey pointed out, the metaphysics of previous epochs had a vital connection to the culture of those epochs, which is why it was able to change the lives of men and women, and not always for the worse. Contemporary analytic metaphysics has no connection with anything but the "intuitions" of a handful of philosophers. It lacks what Wittgenstein called “weight”. (Putnam 1992, p. 197) 
If contemporary analytic metaphysics is a mistake then is the point that we should try to revive traditional metaphysical programs? Or should we perhaps renovate metaphysics so that it will, once again, have "a vital connection" to culture? Or, more radically, is the renewal of philosophy that Putnam calls for a vision of a non-metaphysical form of philosophising-what we might call philosophising without philosophical "musts"? That would certainly fit with the invocation of Wittgenstein and Dewey whose therapeutic aims seem to stand in stark contrast to the program of constructive metaphysics. And it is undeniable that at least part of Putnam's vision of what philosophy ought to be involves resisting the revisionist tendencies of substantial metaphysical programs in order to do justice to our everyday life-world. Philosophy, unlike contemporary analytic metaphysics, ought never to lose contact with the question of how we ought to live or with forms of thought that have 'weight' in our lives.

The question I want to address in this paper is whether this vision spells the end of metaphysics as such or only of a particular kind of metaphysics of which the analytic version is an example? What is the fate of metaphysics on Putnam's conception? Various features of his position might suggest an end of metaphysics reading in something like the spirit of logical positivism. For the positivists, recall, metaphysical expressions are meaningless pseudo-statements lacking any cognitive meaning or truth-value. Such a conception is consistent with Putnam's long-running battle with metaphysical realism, which he describes on more than one occasion as "a metaphysical fantasy" (Putnam 1999, p. 6). This reading can also seem to fit nicely with Putnam's status as a leading neo-pragmatist, the kind of philosopher who, in the words of Richard Rorty, "does not think of himself as any kind of metaphysician" (Rorty 1982, p. xxviii). Furthermore, Putnam's work for more than two decades has shown a strong sympathy with the writings of Ludwig Wittgenstein, who describes his own philosophical project as "bring[ing] words back from their metaphysical to their everyday use" (Wittgenstein 1953, \$116).

On this way of looking at things, Putnam's claim that traditional metaphysics had a vital connection to the cultures in which it flourished can be glossed as a statement about a time when philosophical reflection had yet to reach a stage of maturity from which it could see its way past the construction of metaphysical systems. The recent recrudescence of metaphysics in analytic philosophy has simply failed to see that there is no longer any question of returning to the grand old days of traditional metaphysical inquiry. Metaphysics, on this reading, is nothing but luftgebäude, as Wittgenstein puts it, castles of air (Wittgenstein 1953, \$118).

Although there is more than a grain of truth in this reading, I take it that it misses the depth and complexity of Putnam's attitude to metaphysics. The guiding idea of this paper is that clarity can be shed on this region of Putnam's thought only if it is understood as the latest incarnation of a pragmatist approach to metaphysical systems exemplified in different ways by the work of William James and John Dewey.

The pragmatist approach to metaphysics has been unjustly neglected in contemporary philosophy for two main reasons both having to do with the rise of logical positivism. 
In the first place the prestige of pragmatism has suffered on account of a widespread misreading which regards it as little more than an implausible analysis of truth in terms of verifications and practical benefits. Secondly, the pragmatist approach was eclipsed in the twentieth century by the powerful and sweeping logical positivist conception of metaphysics as meaningless pseudo-statements.

The paper is divided into three parts. The first considers James's appeal to practical factors to help determine whether a metaphysical claim is true. The second turns to Dewey's more skeptical diagnostic approach to metaphysics. And the last part argues that Putnam can be located on the unstable ground that lies between these two positions.

Before turning to consider James, however, it is worth providing a brief sketch, however incomplete and preliminary, of the traditional conception of metaphysics since it is this conception, first and foremost, that the pragmatists are suspicious of.

\section{Traditional metaphysics: a sketch}

The term "metaphysics" was first used to refer to certain works of Aristotle. Traditional metaphysical inquiry as practised in Europe from the middle ages through to the nineteenth century retains a connection to Aristotle's idea of a science of being qua being, the most general study of existence or reality distinct from, and supposedly more fundamental than, any special science. In this traditional conception it is an a priori enquiry concerned to provide a complete and comprehensive explanation of the way the world appears to be in terms of some particular conception of an underlying reality. The metaphysical distinction between appearance and reality departs significantly from the everyday understandings of these terms as concretely applied to, say, the motives of politicians, the shapes of distant objects, or the looks of colours. The 'reality' the metaphysician is concerned with is something hidden and only revealed through some combination of intuition (or revelation) and argument. A crucial assumption of the metaphysician is that if we could comprehend or know this underlying reality then we could provide an absolute or final explanation of the 'appearances' of things, one that is basic and supposed to hold once and for all. Plato's Forms, Leibniz's monads, Kant's things-in-themselves, and Descartes' mental substances are familiar examples of metaphysical entities employed to play a role in this kind of explanation.

A contemporary, and representative, metaphysician is Frank Jackson who writes:

Metaphysics... is about what there is and what it is like... Metaphysicians seek a comprehensive account of some subject matter-the mind, the semantic, or most ambitiously, everything-in terms of a limited number of more or less basic notions... ["Serious metaphysics"] attempt[s] to explain it all... in terms of some limited set of fundamental ingredients. (Jackson 1994, p. 25) 
Note the typical features of traditional metaphysics: the unfamiliar use of the appearance/reality distinction; the claim that some (few) things are fundamental; and the claim that everything can be explained in terms of such things. In this explanation 'appearances' are either to be eliminated or reduced to (or 'located' in) the 'reality' that the metaphysician recognizes as fundamental.

\section{James and the truth of metaphysics}

In his famous volume What is Pragmatism James presents pragmatism, in the first instance, as opposing what he calls intellectualist metaphysics:

[A pragmatist] turns away from abstraction and insufficiency, from verbal solutions, from bad a priori reasons, from fixed principles, closed systems, and pretended absolutes and origins. (James 1975, p. 31).

This dimension of his thought appears to be a rehearsal of the Kantian strategy of eliminating a dogmatic kind of metaphysics in favour of another more acceptable kind. The application of the pragmatic principle-to clarify our ideas or concepts of an object by "consider[ing] what conceivable effects of a practical kind the object may involve" (James 1975, p. 29) - is advertised as undermining rationalist metaphysics but leaving empiricist metaphysics relatively unscathed. Thus James speaks of pragmatism as representative of "the empiricist attitude" (James 1975, pp. 4, 31), an attitude which has "anti-intellectualist tendencies" (James 1975, p. 5). Although he presents pragmatism as "a method only" (James 1975, p. 31), not a metaphysical position, James regards his own metaphysics of experience - the doctrine of radical empiricism-as fitting particularly well with it. Consequently, although inimical to intellectualist metaphysics, pragmatism is presented as at least compatible with, perhaps even sympathetic to, empiricist metaphysics.

But there is another side to James's pragmatism that is in tension with this. In applying the pragmatic maxim to metaphysical claims, if there are no specific experiences to be expected, one must consider the conduct to be recommended and any emotional or other reactions that the object under consideration, supposing it exists, would elicit. James's liberal understanding of what constitutes practical effects puts pressure on him to acknowledge that a pragmatic defence of the intellectualist metaphysics he officially opposes is available.

On James's view it is a significant advantage of pragmatism that traditional metaphysical disputes, which would otherwise be interminably irresolvable on grounds of a priori reason or empirical evidence, are able to be settled by appeal to pragmatic considerations. Thus James writes, 
in every genuine metaphysical debate some practical issue, however conjectural and remote, is involved. (James 1975, p. 5)

James suggests that it is not retrospectively but prospectively that the practical value of metaphysical systems reveals itself. For example, on this basis he argues that the dispute between materialism and theism, which cannot be decided by appeal to epistemic considerations of evidence or explanatory power, can decisively be settled in favour of theism. His claim is that belief in God can satisfy a widespread desire for a philosophy of promise or hope when we consider the future course of the world since "the notion of God... guarantees an ideal [moral] order" (James 1975, p. 6).

Similarly, when James examines the traditional metaphysical topics of substance, the Absolute (of German Idealism), design in nature and free will, the only thing that he decisively rejects on pragmatic grounds is substance, the mere bearer of properties that Locke suspiciously called a we-know-not-what. All the rest provide some basis for an attitude of hope, either by implying that there is an eternal rational order in the universe that does not depend on us or, in the case of free will, by implying that there will be novelties in the future. As these examples demonstrate, a metaphysical topic that might have seemed pointless from either a rational or empirical point of view is revealed as having, at least for a certain class of minds, beneficial pragmatic effects such as feelings of confidence or comfort, particularly when the future course of the world is taken into account.

Like the positivists, James holds that metaphysical disputes are not settled by appeal to empirical evidence or a priori reason. His invocation of pragmatic value makes available non-epistemic reasons to help decide in favour of the truth of one side or the other of a metaphysical dispute that would otherwise be undecidable. That is, James treats the benefits of believing in some metaphysical posit as being part of the rationale for so believing. Consequently, the unreality and unwieldy abstraction of the Absolute, say, which counts against it as far as truth is concerned, is balanced by the fact that since it "yield[s] a religious comfort to a class of minds... [it is] true "in so far forth"” (James 1975, p. 12).

James's pragmatism, then, ultimately has very little anti-metaphysical bite. Whilst he claims to stand opposed to empty intellectualism, whether in the form of merely verbal disputes or metaphysical posits that lack practical value, he is forced to admit that most intellectualist metaphysics is, upon reflection, free of these deficiencies. Pragmatism, for James, makes available new opportunities for discovering which metaphysics is true all things considered. 


\section{Dewey and the content of metaphysics}

Dewey is a more robustly anti-metaphysical thinker than James although, as we will see, there is an important qualification to be made. By conceiving philosophy as a broadly empirical method of inquiry, Dewey renders traditional metaphysics (or "absolutistic philosophies") obsolete. Dewey's experimentalism leaves no room for any purely a priori inquiry into the (putatively) hidden and fixed nature of the world. Of the problems of traditional metaphysics Dewey writes, "We do not solve them; we get over them" (Dewey 1910, p. 7). In contrast to James, he does not think that a consideration of the practical significance of metaphysical systems provides any vindication of them. Two main points of difference are worth noting: 1) For James, practical significance is a criterion of the truth of a metaphysical system; whereas for Dewey it primarily bears on the question of its content; and 2) Dewey's conception of the practical significance of a metaphysical system is rooted in the social and historic conditions under which that system was invented and flourished. James's account, alternatively, focuses on the relation of metaphysics to allegedly trans-historic human needs such as "the need of an eternal moral order" (James 1975, p. 6). Dewey remarks,

Metaphysics is a substitute for custom as the source and guarantor of higher moral and social values - that is the leading theme of the classic philosophy of Europe, as evolved by Plato and Aristotle... [and] renewed and restated by the Christian philosophy of Medieval Europe. (Dewey 1967-90, vol. 12, p. 89)

Metaphysics is here seen as the illusion of a timeless foundation for what are in fact local and changeable moral and social values. At the same time it is, together with traditional epistemology, a consolation of the purely speculative mind for its inability to change the world:

In truth, historic intellectualism, the spectator view of knowledge, is a purely compensatory doctrine which men of an intellectual turn have built up to console themselves for the actual social impotency of the calling of thought to which they are devoted. (Dewey 1957, p. 117)

Of course this conception of metaphysics is not one that the metaphysician himself could reflectively endorse. Dewey's is a diagnostic approach that implies that metaphysics characteristically involves self-deception. It is not really a study of the timeless, universal or necessary features of reality, as it takes itself to be, for there is no such thing on Dewey's view. It plays an imaginary role of apparently securing a transcendent account of the source and authority of what is, in reality, attributable to custom and human history. Metaphysics thus consoles us for its inability to play any genuine or authentic moral or social function. 
This account, far from vindicating metaphysics, is no less destructive of it than logical positivism is. Metaphysical questions lack genuine empirical or practical value, and the apparent authority they provide for a community's moral and social values is a grand illusion. Perhaps one should add that Dewey is sensitive to the way in which such illusions can, nonetheless, be forces in world history. But he is the last person to want to perpetuate these myths. So, if the moral function of metaphysics cannot be appealed to as a defence of it and one has followed Dewey in abandoning a priori inquiry, what hope is there for the future of metaphysics? In this vein he writes,

Is there not reason for believing that the release of philosophy of its burden of sterile metaphysics and sterile epistemology instead of depriving philosophy of problems and subject-matter would open a way to questions of the most perplexing and the most significant sort? (Dewey 1957, p. 126)

Nonetheless, in spite of the strongly anti-metaphysical tendencies of his thinking, Dewey surprisingly follows James in attempting to articulate what he calls a "metaphysics" of experience. The tension in Dewey's position is mitigated to some extent by an explicit attempt to employ the old metaphysical vocabulary in a new more pragmatic spirit. Thus, what he calls "metaphysics" is not concerned with fixed essences, ultimate origins or ultimate ends but with what he calls "the more ultimate traits of the world" which he goes on to identify with "certain irreducible traits found in any and every subject of scientific inquiry" (Dewey 1967-90, vol. 8, p. 4). Examples of the objects of metaphysical inquiry in this sense include diversity, interaction, and change. Whereas traditional metaphysics typically concerns itself with the fixed and final, Dewey's metaphysics concerns itself with the fluid and incomplete. The impression that Dewey has cut off the branch he is attempting to sit on is confirmed when we ask what this new metaphysics consists in. What are its discoveries or insights? Dewey provides nothing but vague and disappointing generalities which do not have any of the power of his diagnostic claims or, for that matter, of the great metaphysical systems of the past. In a particularly revealing passage he writes:

This is the extent and method of my "metaphysics": - the large and constant features of human sufferings, enjoyments, trials, failures and successes together with the institutions of art, science, technology, politics, and religion which mark them, communicate genuine features of the world within which man lives. The method differs not a whit from that of any investigator who, by making certain observations and experiments, and by utilizing the existing body of ideas available for calculation and interpretation, concludes that he really succeeds in finding out something about some limited aspect of nature. (Dewey 1927, p. 59)

What are the "large and constant features" of the human condition or, more broadly still, of what he elsewhere calls "the generic traits manifested by existences of all kinds" 
(Dewey 1929, p. 412)? And even if we can give content to such vague and general pronouncements about the human condition or all existences, why call it metaphysics rather than anthropology or history, especially if the method is the same as that of the social scientist?

Dewey eventually gave up his attempt to reinterpret metaphysics to fit his own pragmatist standpoint. The tension in Dewey's conception finally led to his complete renunciation of metaphysics. In a reply to a critic in 1949, Dewey writes,

I now realize that it was exceedingly naïve of me to suppose that it was possible to rescue the word ["metaphysics"] from its deeply ingrained traditional use. I derive what consolation may be possible from promising myself never to use the word again in connection with any aspect of any part of my own position. (Dewey 1949, pp. 712-13)

To take this remark seriously is to see Dewey as having a fundamentally therapeutic attitude to metaphysics all along. His mistake was to suppose there was any point in trying to rescue the term in the radically new setting of pragmatism.

\section{Putnam and the insights of metaphysics}

Let us sum up the pragmatist stance to metaphysics as exemplified in James and Dewey. The pragmatist is presented as a critic of the traditional intellectualist metaphysician and of the merely verbal disputes often associated with such metaphysics. He is more congenial to a metaphysics of experience. More importantly, pragmatism is perhaps the first philosophical movement to seriously consider the practical function of a metaphysics: as a source of spiritual comfort; or an apparent guarantor of the moral and social order; or a consolation for political impotence. For James this provides some reason to think a metaphysics is true; for Dewey, on the contrary, it shows that metaphysics is inescapably bound up with self-deception or what existentialists call bad faith. For Dewey, the illusion that there is a fixed, underlying realm of Being is a consequence to the human capacity to transcendentalize or eternalize the timebound values of a particular society. Thus James's appeal to the pragmatic significance of metaphysics tends to be vindicatory; whereas Dewey's tends to be undermining.

Now let us ask: where does Putnam stand on these issues? Is he a Jamesian apologist for metaphysics or a Deweyan critic of the enterprise? As I hope will become clear I read Putnam as sharing aspects of both the positions of James and Dewey, an uneasy position that is not without internal tension. I shall end this paper by raising some questions about how this tension might be overcome. 
In the first place, Putnam is certainly a strong critic of the foundationalist and essentialist pretensions of traditional metaphysics. A representative passage reads:

the long history of failures to explain in metaphysical terms how mathematics is possible, how nondemonstrative knowledge is possible... and so on, suggests nothing much follows from the failure of philosophy to come up with an explanation of anything in "absolute terms"-except, perhaps, the senselessness of a certain sort of metaphysics. (Putnam 2002, p. 45)

Putnam reserves his strongest criticisms for the many and various attempts to explain away or denigrate our everyday ethical thought and talk in metaphysical terms whether by way of the contrasts between cognitivism and non-cognitivism (e.g. Simon Blackburn), facts and values (e.g. A.J. Ayer), or absolute and perspectival knowledge (e.g. Bernard Williams).

Perhaps Putnam's most well-known anti-metaphysical program has been his attempt to salvage a small " $\mathrm{r}$ " realism-qualified at one time as "internal" and, more recently, as "pragmatic" or "natural" - from big " $R$ " Metaphysical Realism. His criticisms are too familiar to rehearse again in this context. What I want to call attention to is that Putnam explicitly avoids the Kantian strategy: he is careful to distinguish natural realism from any kind of metaphysical theory that might be imagined to superannuate Metaphysical Realism. Natural realism is rather an attempt to salvage a common sense attitude towards the world that metaphysics (and skepticism) is thought to ultimately deny or denigrate. We might think of this as representing the Deweyan dimension of his approach.

Like both James and Dewey, and in contrast to the logical positivists, Putnam does not regard traditional metaphysics as totally lacking in cognitive content. He explains,

To call upon us to renounce... the dreams of metaphysics... is not at all to join the logical positivists of yesteryear in calling... metaphysics... 'nonsense'. There is much of permanent value in the writings of... traditional metaphysicians. It would be false to Dewey's own spirit to deny that there is. (Putnam 2004, p. 105)

But what does Putnam mean by "permanent value" in this context? Putnam takes himself to be following Dewey here but his thought is, in fact, much closer to James. Putnam is inclined, for all of his criticisms of traditional metaphysics, to think that this region of philosophy contains valuable insights. Dewey, as we have seen, takes a more Wittgensteinian or diagnostic approach which attempts to explain metaphysics as an understandable intellectual distortion or "divination" of aspects of our familiar world for understandable reasons such as our fear of change or the theorist's need for consolation for being unable to change the world for the better. Dewey, in short, does 
not look to metaphysics as a rich seam of insights; he looks to it, rather, as an all-toohuman indulgence in mythology and consoling self-deception.

To illustrate this difference it is worth comparing the different ways in which Dewey and Putnam think about the role of the imagination in metaphysics. Dewey holds that a human being is "primarily a creature of the imagination" (Dewey 1957, p. 118) and that this has an important bearing on the way in which we understand what motivates metaphysical speculation. On his view, an important difference between metaphysics and scientific inquiry lies in two different employments of the same idealizing function of the imagination. In metaphysical thinking there is a tendency to treat ideals and idealizations as realities by forgetting that they are products of human intellectual activity, often arising out of everyday experiences but, as Dewey puts it, "with their blemishes removed, their imperfections eliminated, their lacks rounded out, their suggestions and hints fulfilled" (Dewey 1957, pp. 105-106). Plato's Forms are a classic example. The metaphysician Plato not only treats these ideals as perfect, singular and unchangeable entities but as more real than the mundane realities of the world in which we live our lives. For a scientist, or a scientifically-minded pragmatist, however, ideals and idealizations are seen as imaginative tools that help to explain or understand highly complex real-world objects or events. An ideal or idealization, like an architectural model, is not to be assessed as simply true or false. Its role is, rather, to illuminate by way of analogy some, but by no means all, of the important features of the target phenomena.

The moral is that although metaphysics arises from a natural, indeed laudable, capacity for idealization - a capacity that includes the construction of models and imagined possibilities-Dewey sees metaphysical system-building as an undisciplined employment of this capacity, one that depends on forgetting the schematic character of ideals, and their context-sensitive utility in highlighting some features of a particular thing to the exclusion of others. Dewey's diagnostic approach is not a matter of seeing metaphysics as containing various truths, however indirect. It would be better to say that metaphysics has its source in a useful capacity which, when properly employed (e.g. in scientific theorizing), can lead to fruitful discoveries.

Putnam follows Dewey (and Wittgenstein) in thinking that the imagination plays a central role in motivating metaphysical thinking but he conceives this role in a more Jamesian spirit. Putnam employs Wittgenstein's notion of a picture which can be variously understood as: what we would ordinarily call a picture e.g. a drawing or diagram; or a mental image; a rough and ready conception; an engineer's model e.g. of a bridge; and so on. A picture, we might say, is a rough and ready or schematic way of seeing things that is to be contrasted with a fully elaborated theory.

What, then, is the relation between pictures and metaphysics? Consider the following passage in which Putnam is comparing what he calls the picture of metaphysical realism with the idealist picture of truth as consisting in idealized warranted assertibility, 
I think the idealist "picture" calls our attention to vitally important features of our practice-and what is the point of having "pictures" if we are not interested in seeing how well they represent what we actually think and do. (Putnam 1990, p. 42)

This passage strongly suggests a representationalist conception of pictures according to which they represent the world well or badly. I take it that the pictures themselves are not simply true or false but that they can, through a certain use or employment, bring "vitally important features of our practices" to our attention, and, in that sense, represent the world. The Jamesian suggestion seems to be that traditional metaphysics, in so far as it is a matter of using pictures, can indirectly represent features of the world that we would otherwise miss. This constitutes part of its "permanent value".

\section{The end of metaphysics?}

Where do these reflections leave the fate of metaphysics? We have seen how Dewey, despite some equivocation, is charitably interpreted as having an end of metaphysics stance. His equivocation is not a matter of thinking that traditional metaphysics has any life left in it; it is, rather, a matter of thinking that metaphysics can be reconcieved and rehabilitated on a pragmatist basis. As we have seen, Dewey has a more nuanced approach to traditional metaphysics than the positivists. He provides a rich account of its motivations in various entrenched human capacities, needs and desires but for all that his account is not a vindication of metaphysics, as James's account tends to be. A central part of his view is that metaphysicians do not realize the nature or sources of their own thinking. If they did, they would be out of business.

Putnam's attitude to the fate of metaphysics seems to be located somewhere between Dewey and James. He writes,

I take it as a fact of life that there is a sense in which the task of philosophy is to overcome metaphysics and a sense in which its task is to continue metaphysical discussion. (Putnam 1988, p. 457)

The difficulty in interpreting this comment is to understand in what sense it is the task of philosophy to continue metaphysical discussion. Putnam has made it quite clear that he thinks almost all current analytic metaphysics, and large tracts of traditional metaphysics, are a matter of "dreams", "fantasies", "confusions" and "ridiculous" ideas. This fits well with the Deweyan (and Wittgensteinian) idea that an important task for philosophy is to overcome metaphysics. But, like James in particular, he has also claimed that there are salvageable insights in at least some of the great systems of traditional metaphysics. These insights, however, were certainly not the insights the metaphysicians themselves believed they had discovered. For Putnam, there is no fixed realm of 
essences or necessary truths of the sort the metaphysicians of old dreamed that they had discovered. One example is worth considering further.

In lectures delivered at Harvard Putnam held that the insight in Metaphysical Realism (an insight owed to James) is that words do indeed correspond to realities but that there are many different kinds of correspondence relation in question not a single relation as the Realist had supposed. But, note, that this insight salvaged from the metaphysical picture of a single word-world relation is not a distinctively metaphysical insight and it is certainly not the insight the Metaphysical Realists themselves supposed they had found.

Putnam follows Dewey and Wittgenstein in holding that the metaphysician is subject to the illusion of taking products of his own imagination for realities. If that is so, then how could a contemporary metaphysician engage in metaphysical discussion without illusion, or self-deception, or forgetting that his pictures are pictures? In approaching this question it is worth reflecting that throughout the discussion we have been assuming that metaphysics is a fairly well-circumscribed concept for an a priori inquiry into eternal essences or fixed and necessary structures of the world. But what of a philosopher who holds that what reality is really like does not include essences? Surely this is still a metaphysical stance even if it is anti-essentialist. Or one could hold that there are essences or fixed necessities but they are in the mind or perhaps language rather than the external world. Surely that counts as metaphysics too. Or what of a philosopher like Quine who claims to forgo a priori theorizing but retains elements of empiricism or physics worship that seem like elements of a first philosophy (in so far as they are not subject to revision)? One is tempted to call these elements metaphysical too. The point is that since there are many forms that the metaphysical aspiration to explain appearances in terms of some underlying reality can take, the concept of the metaphysical is itself not fixed but evolves. It is what Wittgenstein calls a family resemblance concept. The traditional search for essence prompted by the Socratic question "What is $\mathrm{X}$ ?" is simply the most important historical paradigm of metaphysics. But metaphysics also includes Kant's transcendental question "How is X possible?" as well as the modern search for the necessary and sufficient conditions for the application of a concept.

Consequently, it can be hard to say what counts as a metaphysics in any given case, especially if Wittgenstein is right in thinking that metaphysics often dresses itself up as science. So one reason for thinking that we will continue metaphysical discussion is that it is often unclear whether certain expressions are being employed for metaphysical purposes or not. The question of discerning what is metaphysical and what not thus becomes an important matter for philosophical investigation. But even if that is so it is not obvious that this exhausts what Putnam means by speaking of the continuation of metaphysical discussion-although it does seem clear that his renewed vision of philosophy is incompatible with the metaphysical system-building of, say, a David Lewis or a David Armstrong. 
Putnam's remarks suggest that philosophy will always engage in metaphysical discussion in at least the relatively weak sense that we are creatures who, given the facts of our human nature-our wants, wishes, imaginings, etc.- - will inevitably drift into asking metaphysical questions and urging metaphysical answers. This view is compatible with a primarily therapeutic conception of philosophy that sees its aim as one of exposing and interrogating metaphysical pronouncements with a view to overcoming them, endlessly, one by one. This would be to embrace an end to metaphysical systembuilding whilst acknowledging that there will be no end to the urge to metaphysics.

Alternatively, Putnam may think, as Dewey sometimes did, that there is a viable reconception of metaphysics that is distinct from traditional metaphysics. In the same vein, Strawson (1959) supposed that an investigation of the general features of our conceptual network is a kind of metaphysics, which he called "descriptive metaphysics". We might think of it as contributing to a conception of philosophy as the attempt "to understand how things, in the broadest possible sense of the term hang together in the broadest possible sense of the term" (Sellars 1963, p. 1). But this attempt to redefine the term 'metaphysics' is prone to lead to confusion, as Dewey finally saw. The aim of 'descriptive metaphysics' is to describe something that lies open to view-uses of language, concepts as employed in judgments - not to explain the 'appearances' in terms of something hidden i.e. some metaphysical reality. And it has no trouble accepting that our concepts are contingent, changeable and responsive to human needs. If one is tempted to make this move it is important not to lose sight of the great difference between, on the one hand, engaging in traditional metaphysics and, on the other, responding to traditional metaphysical questions by, in effect, changing the subject to engage in piecemeal descriptions of our concepts and their uses.

\section{REFERENCES}

Ayer A. ed. (1959), Logical Positivism, New York: The Free Press

Cahn S.M. ed. (1977), New Studies in the Philosophy of John Dewey, Hanover: The University Press of New England

Cartwright N. (1999), The Dappled World: A Study of the Boundaries of Science, Cambridge: Cambridge University Press

Dewey J. (1965/1910), The Influence of Darwin on Philosophy and Other Essays in Contemporary Thought, Bloomington: Indiana University Press

Dewey J. (1929/1925), Experience and Nature, London: George Allen \& Unwin

Dewey J. (1927), “Half-Hearted Naturalism”, Journal of Philosophy, 24, pp. 57-64

Dewey J. (1949), “Experience and Existence: A Comment”, Philosophy and Phenomenological Research, 9, pp. 709-713

Dewey J. (1957/1920), Reconstruction in Philosophy, Boston: Beacon Press

Dewey J. (1967-90), The Collected Works of John Dewey. 1882-1953, Carbondale: Southern Illinois University Press, electronic edition 
Godfrey-Smith P. (2006), “Theories and Models in Metaphysics", Harvard Review of Philosophy, 14, pp. 4-19

Henrich D. \& R.P. Horstmann eds. (1988), Metaphysik nach Kant?, Stuttgart: Klett-Cotta

Jackson F. (1994), From Metaphysics to Ethics, Oxford: Oxford University Press

James W. (1975), Pragmatism and The Meaning of Truth, Cambridge: Harvard University Press

Kant I. (1929/1789), Critique of Pure Reason, trans. N. Kemp-Smith, London: Macmillan

Pears D. ed. (1962), The Nature of Metaphysics, London: Macmillan

Putnam H. (1988), “After Metaphysics, What?”, in Henrich \& Horstmann 1988, pp. 457-466

Putnam H. (1990), Realism with a Human Face, Cambridge, Mass.: Harvard University Press

Putnam H. (1992), Renewing Philosophy, Cambridge, Mass.: Harvard University Press

Putnam H. (1999), The Threefold Cord, New York: Columbia University Press

Putnam H. (2002), The Collapse of the Fact/Value Dichotomy and Other Essays, Cambridge, Mass.: Harvard University Press

Putnam H. (2004), “The Uniqueness of Pragmatism”, Think, 8, pp. 89-105

Rorty R. (1977), “Dewey’s Metaphysics”, in Cahn 1977, pp. 45-74

Rorty R. (1982), Consequences of Pragmatism, Minneapolis: University of Minnesota Press

Sellars W. (1963), Science, Perception and Reality, London: Routledge

Strawson P. (1959), "Introduction", in Strawson 1958, London: Methuen

Strawson P. (1959), Individuals, London: Methuen

Warnock M. (1962), "Final Discussion”, in Pears 1962, pp. 142-162

Wittgenstein L. (1953), The Philosophical Investigations, London: Blackwell

Wittgenstein L. (1967), Zettel, Berkeley: University of California Press

Received: January 9, 2008

Accepted: August 28, 2008

Department of Philosophy

Room S412, Main Quad A 14

University of Sydney NSW 2006

Sydney, Australia

david.macarthur@usyd.edu.au 